\title{
Pengenalan Wajah Menggunakan Metode Viola-Jones dan Eigenface Dengan Variasi Posisi Wajah Berbasis Webcam
}

\author{
Aries Suharso \\ Universitas Singaperbangsa Karawang, Fasilkom, Teknik Informatika \\ aries.suharso@unsika.ac.id \\ Jl. HS.Ronggo Waluyo, Telukjambe Timur, Karawang, Jawa Barat 41361
}

\begin{abstract}
ABSTRAK
Pengenalan citra wajah manusia merupakan salah satu teknologi penting yang terus berkembang pada bidang computer vision dengan penerapannya dalam sistem keamanan, sistem kontrol, dan lain sebagainya. Pengenalanan wajah yang diusulkan menggunakan objek wajah yang bervariasi posisinya dari hasil capture pada sebuah webcam yang terkoneksi pada sebuah komputer. Metode Viola-Jones digunakan untuk mendeteksi wajah dan metode eigenface digunakan untuk mengenali wajah, aplikasi yang dibangun menggunakan Microsoft visual studio dan fungsi capture pada webcam menggunakan OpenCV. Uji coba dilakukan pada intensitas cahaya normal dengan jarak dan posisi wajah yang telah ditentukan, pengolahan data uji dilakukan menggunakan Matlab. Hasil dari penelitian ini menunjukkan tingkat akurasi deteksi citra wajah sebesar $88.89 \%$ dengan sudut rotasi variasi posisi citra wajah menghadap ke depan (frontal) $-15^{\circ}$, kesamping kiri $30^{\circ}$ dan kanan $30^{\circ}$ dan terbukti pada nilai threshold 75 memiliki akurasi tertinggi dan jumlah dikenali tertinggi yaitu sebesar 90.90\%.
\end{abstract}

Kata Kunci : deteksi wajah, pengenalan wajah, variasi posisi, Viola-Jones, eigenface.

\section{PENDAHULUAN}

Saat ini telah banyak berkembang sistem yang memanfaatkan fitur deteksi wajah diantaranya yaitu sistem akses keamanan maupun sistem kontrol. Deteksi wajah sendiri dapat dilakukan dengan berbagai cara, salah satunya menggunakan metode Viola-Jones, yaitu metode yang menggabungkan support vector machines, algoritma boosting, dan cascade classifier. Metode ini kemudian diterapkan pada suatu sembarang citra digital, untuk mendapatkan citra wajah manusia dengan beberapa posisi wajah yang berbeda. Metode ini relative mendapatkan hasil yang cepat, akurat, dan efisien. Metode Viola-Jones merupakan algoritma yang paling banyak digunakan untuk mendeteksi wajah, dimana proses pendeteksian wajah dilakukan dengan mengklasifikasikan sebuah gambar setelah sebelumnya melalui sebuah pengklasifikasi yang dibentuk dari data latih.

Walaupun telah banyak dilakukan pengembangan pada deteksi dan pengenalan citra wajah namun hasilnya masih jauh dari kesempurnaan, terlebih sedikit yang membahas tentang deteksi citra wajah manusia berdasarkan variasi posisi wajah. variasi posisi wajah yang dimaksud pada penelitian ini adalah sudut kemiringan wajah dan jarak wajah manusia terhadap camera yang digunakan sebagai alat input capture image untuk diproses selanjutnya.

Penelitian ini berbentuk eksperimen rekayasa perangkat lunak yang luarannya berupa aplikasi dengan data dari penelitian ini berupa sampel citra yang dicapture dari sebuah webcam yang terhubung dengan komputer. Citra wajah manusia yang diambil berbeda-beda dengan masing-masing mendapatkan perlakuan variasi yang sama yaitu : kemiringan sudut posisi citra wajah, jarak wajah terhadap camera webcam dan intensitas cahaya.

\section{METODE PENELITIAN}

\subsection{Peubah yang diamati}

Data yang digunakan dalam penelitian ini berupa sampel gambar yang diambil dari hasil capture sebuah camera webcam, dengan beberapa batasan aspek, yaitu : variasi posisi citra wajah, jarak wajah terhadap camera webcam dan intensitas cahaya.

Untuk variasi posisi wajah dilakukan beberapa posisi sebagai berikut :

- menghadap ke depan (frontal),

- rotasi sejajar $30^{\circ}, 45^{\circ}, 60^{\circ}$, dan $75^{\circ}$ ke kanan,

- rotasi sejajar $30^{\circ}, 45^{\circ}, 60^{\circ}$, dan $75^{\circ}$ ke kiri, 
- $\quad$ mengangkat dagu $-15^{0}, 15^{0}$ dan $30^{\circ}$ ke atas,

- menunduk kepala $-15^{0}, 15^{0}$ dan $30^{\circ}$ ke bawah,

wajah yang dicapture webcam tidak terhalangi sebagian oleh objek lain, tidak banyak terpotong dan tidak bergerak.

Untuk aspek jarak wajah terhadap camera webcam akan dicari jarak ideal antara 50cm hingga $200 \mathrm{~cm}$. Sedangkan untuk aspek intensitas cahaya ditetapkan pada kondisi normal dengan cahaya cukup yaitu pagi hari sekitar jam 10:00 wib.

\subsection{Model yang digunakan}

Pada penelitian ini akan digunakan gabungan dua buah metode, yaitu metode untuk mendeteksi citra wajah manusia menggunakan metode Viola-Jones dan metode untuk pengenalan wajah seseorang menggunakan metode eigenface. Adapun lokasi penelitian berpusat di Laboratorium Komputer Fasilkom Universitas Singaperbangsa Karawang.

\subsection{Rancangan Penelitian}

Berikut ini merupakan skema proses deteksi wajah menggunakan metode Viola-Jones.

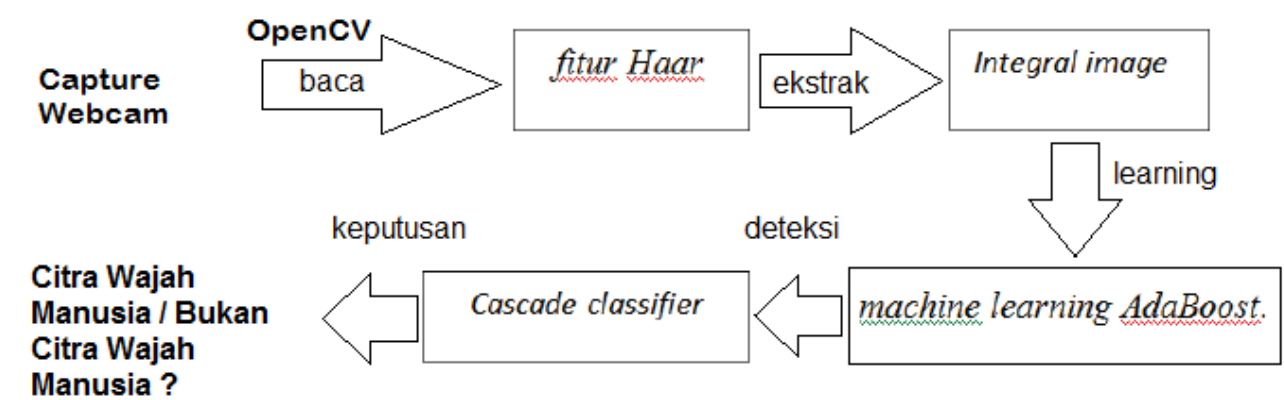

Gambar 2.1 Alur Proses Deteksi Citra Wajah Manusia menggunakan Metode Viola-Jones.

Hasil deteksi wajah dari metode viola jones selanjutnya dijadikan bahan untuk pengenalan wajah pada metode Eigenface.

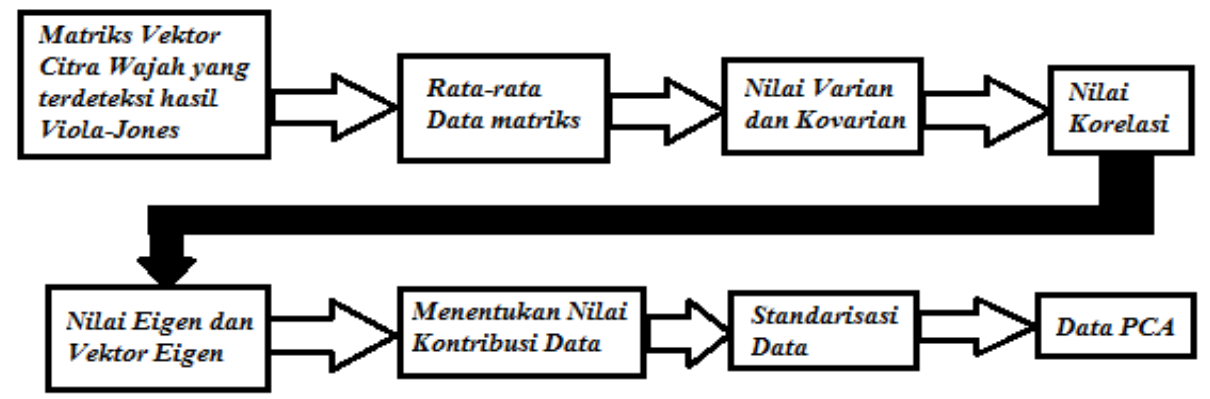

Gambar 2.2 Alur Proses Pengenalan Citra Wajah Manusia menggunakan Metode Eigenface

\subsection{Teknik pengumpulan dan Analisis Data}

Data yang dikumpulkan merupakan data yang berupa citra kondisi fisik wajah seseorang yang diekstrak menjadi matriks vektor hasil komputasi dan analisis menggunakan Matlab. Analisis data dilakukan melalui serangkaian uji klasifikasi untuk pendeteksian wajah pada metode viola-jone dan uji korelasi citra wajah data latih untuk pengenalan wajah pada metode eigenface.

\subsection{Penafsiran dan penarikan kesimpulan}

Evaluasi hasil kinerja dari model pengenalan wajah metode Viola-Jones dan Eigenface dilakukan dengan berdasarkan pertimbangan nilai precision dan false positive rate yang membuktikan tingkat akurasi dari model pengenalan wajah yang diusulkan. 


\section{PEMBAHASAN \\ Membaca fitur Haar.}

Langkah awal yang dilakukan pada metode deteksi wajah Viola-Jones adalah membaca sampel gambar oleh MATLAB R2010a. Fitur Haar adalah fitur yang digunakan dalam metode ViolaJones yang dapat juga disebut fitur gelombang tunggal bujur sangkar (satu interval tinggi dan satu interval rendah), sedangkan untuk dua dimensi disebut sebagai satu terang dan satu gelap. Adanya fitur Haar ditentukan dengan cara mengurangi rata-rata piksel pada daerah gelap dari rata-rata piksel pada daerah terang.

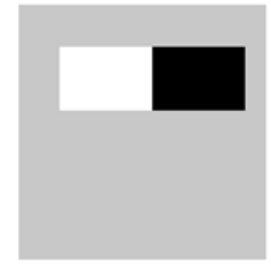

(a)

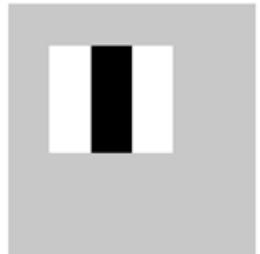

(b)

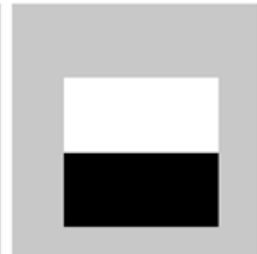

(c)

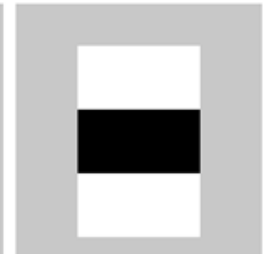

(d)

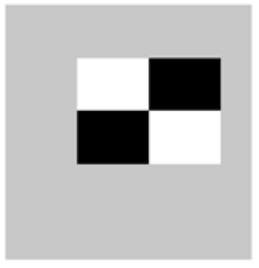

(e)

Gambar 3.1 Fitur Haar

Jika nilai perbedaannya itu di atas nilai ambang atau treshold, maka dapat dikatakan bahwa fitur tersebut ada. Selanjutnya untuk menentukan ada atau tidaknya dari ratusan fitur Haar pada sebuah gambar dan pada skala yang berbeda secara efisien digunakan Integral Image.

Untuk memperoleh perbedaan kondisi tingkat kecerahan, maka seluruh citra harus dalam bentuk nilai rata-rata yang telah dinormalisasikan dari variasi sebelumnya. Seluruh citra tersebut memiliki nilai variasi yang lebih rendah dibandingkan yang lainnya memiliki sedikit informasi maka akan dibuang dari penilaian.

Seperti yang terlihat pada gambar 3.1 fitur haar, latar belakang pada template (b) yang berwarna keabuan ke arah bagian warna yang lebih terang. Selanjutnya hanya pixel pada bagian yang diberi tanda saja yang digunakan saat dihubungan dengan perhitungan fitur.

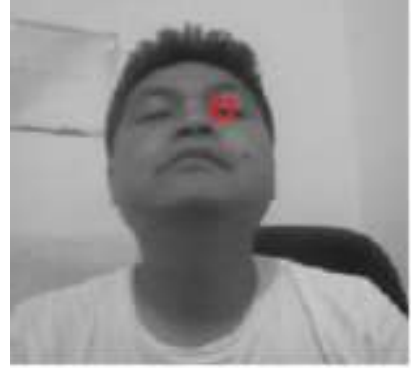

(a)

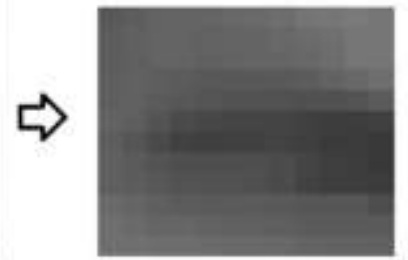

pixel $10 \times 10$

(b)

Gambar 3.2 Potongan pixel pada fitur haar

Contoh penghitungan nilai pixel suatu image dapat ditunjukkan seperti pada gambar 3.2 dipilih daerah yang bertanda kotak merah dengan utukan pixel 10x10, selanjutnya dihitung dengan Matlab sehingga menghasilkan bentuk matrik sebagai berikut ;

$\begin{array}{rrrrrrrrrr}93 & 97 & 101 & 100 & 98 & 101 & 101 & 101 & 108 & 112 \\ 93 & 96 & 100 & 100 & 97 & 100 & 101 & 102 & 105 & 109 \\ 95 & 98 & 94 & 91 & 89 & 88 & 89 & 90 & 92 & 99 \\ 95 & 97 & 92 & 88 & 85 & 83 & 82 & 81 & 80 & 82 \\ 99 & 94 & 85 & 75 & 72 & 69 & 69 & 68 & 64 & 62 \\ 95 & 86 & 75 & 65 & 63 & 64 & 66 & 67 & 64 & 60 \\ 97 & 91 & 84 & 79 & 78 & 78 & 78 & 75 & 69 & 63 \\ 96 & 93 & 88 & 84 & 83 & 82 & 80 & 75 & 67 & 62 \\ 106 & 101 & 96 & 92 & 91 & 91 & 91 & 90 & 87 & 86 \\ 112 & 106 & 101 & 102 & 99 & 97 & 96 & 94 & 91 & 90\end{array}$

Gambar 3.3 Nilai Pixel

Berkat batasan ini, sejumlah fitur dapat dimunculkan dari sebuah citra untuk selanjutnya dikelola. Sebagai contoh pada gambar 3.3 di atas dengan ukuran 10x 10 pixel memiliki 43200, 27600, 
43200, 27600 dan 20736 fitur dengan kategori (a), (b), (c), (d), dan (e) secara berurutan, sehingga diperoleh 162336 fitur seluruhnya.

Diharapkan dari fitur yang diambil terdapat informasi yang diperlukan sebagai karakter wajah dan citra wajah mampu dideteksi oleh fitur haar secara alamiah. Oleh karena itu walau bagaimanapun beberapa hal yang krusial menyebabkan kumpulan fitur haar ini menjadi berurutan.

\section{Integral Image.}

Integral Image adalah sebuah citra yang nilai tiap pikselnya merupakan penjumlahan dari nilai pixel kiri atas hingga kanan bawah. Integral image memungkinkan penghitungan pixel secara mudah dengan biaya yang murah, hitungan berdasarkan jumlah seluruh pixel yang terkandung dalam batasan jendela fitur haar, teknik pencerminan digunakan untuk distribusi fungsi kumulatif.

Contoh integral image dapat dilihat pada Gambar 3.4 :

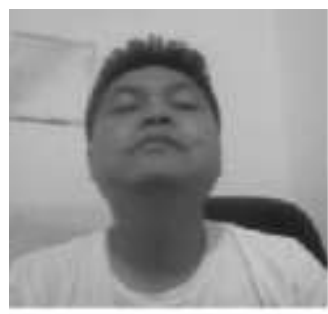

(a)

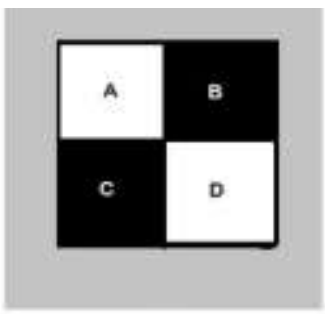

(b)

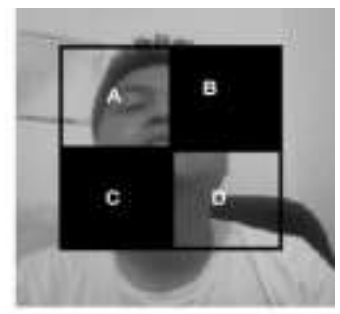

(c)

Gambar 3.4 Perhitungan Integral image

Dengan menggunakan integral image dapat mengetahui nilai pixel untuk beberapa segiempat yang lain misalkan, seperti segiempat D pada Gambar 3.4 di atas dapat dilakukan dengan cara menggabungkan jumlah piksel pada area segiempat $\mathrm{A}+\mathrm{B}+\mathrm{C}+\mathrm{D}$, dikurangi jumlah dalam segiempat $\mathrm{A}+\mathrm{B}$ dan $\mathrm{A}+\mathrm{C}$, ditambah jumlah piksel di dalam $\mathrm{A}$. Dengan $\mathrm{A}+\mathrm{B}+\mathrm{C}+\mathrm{D}$ adalah nilai dari integral image pada lokasi $4, \mathrm{~A}+\mathrm{B}$ adalah nilai pada lokasi 2, A+C adalah nilai pada lokasi 3, dan A pada lokasi 1. Sehingga hasil dari $D$ dapat dikomputasikan $D=(A+B+C+D)-(A+B)-(A+C)+A$. Untuk memilih fitur yang spesifik yang akan digunakan dan untuk mengatur nilai ambangnya (threshold), Viola dan Jones menggunakan sebuah metode machine learning yang disebut AdaBoost. AdaBoost menggabungkan banyak classifier lemah untuk membuat sebuah classifier kuat. Lemah disini berarti urutan filter pada classifier hanya mendapatkan jawaban benar lebih sedikit.

Pada umumnya, pengintegrasian tersebut menambahkan unit-unit kecil secara bersamaan. Dalam hal ini unit-unit kecil tersebut adalah nilai-nilai piksel. Nilai integral untuk masing-masing piksel adalah jumlah dari semua piksel - piksel dari atas sampai bawah. Dimulai dari kiri atas sampai kanan bawah, keseluruhan gambar itu dapat dijumlahkan dengan beberapa operasi bilangan bulat perpiksel. Kemudian untuk memilih fitur Haar yang spesifik yang akan digunakan dan untuk mengatur nilai ambangnya (threshold) digunakan sebuah metode machine learning yang disebut AdaBoost.

\section{Machine Learning Adaboost.}

AdaBoost menggabungkan banyak classifier lemah untuk membuat sebuah classifier kuat. dengan menggabungkan beberapa AdaBoost classifier sebagai rangkaian filter yang cukup efisien untuk menggolongkan daerah image. Masing - masing filter adalah satu AdaBoost classifier terpisah yang terdiri classifier lemah atau satu filter Haar. Selama proses pemfilteran, bila ada salah satu filter gagal untuk melewatkan sebuah daerah gambar, maka daerah itu langsung digolongkan sebagai bukan wajah. Namun ketika filter melewatkan sebuah daerah gambar dan sampai melewati semua proses filter yang ada dalam rangkaian filter, maka daerah gambar tersebut digolongkan sebagai wajah.

Pada proses selanjutnya Machine Learning Adaboost juga digunakan untuk mengenali identitas wajah seseorang setelah data wajah orang tersebut disimpan dalam suatu kumpulan (galeri) data latih. 


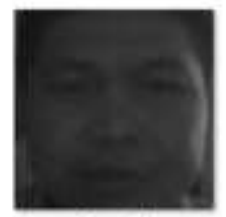

face1

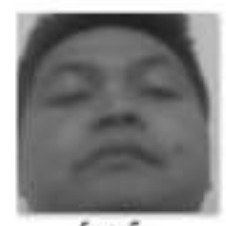

faces

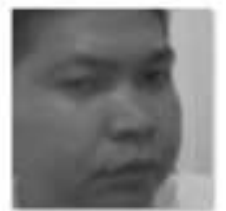

faceg

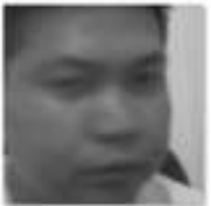

face13

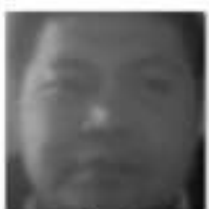

face2

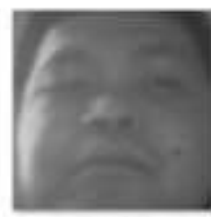

face6

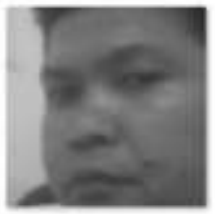

face10

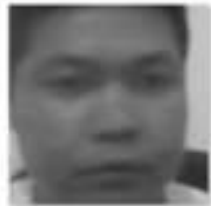

face14

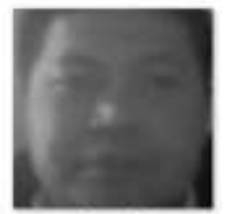

face 3

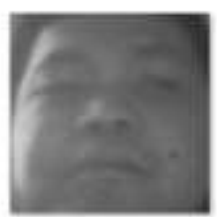

face?

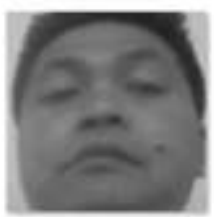

face11

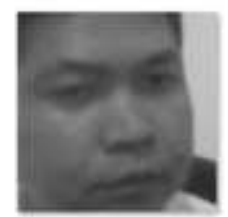

facels

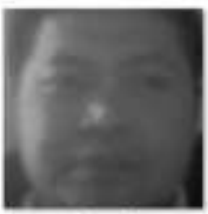

face 4

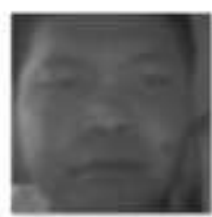

face8

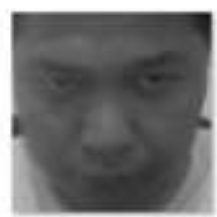

face 12

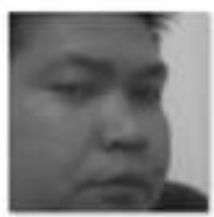

face16

Gambar 3.5 Galeri Data Latih

Kemudian melalui mekanis klasifikasi pada Machine Learning Adaboost dilakukan proses pencocokan data dari input wajah seseorang, seperti ditunjukkan pada gambar 4.7 berikut.

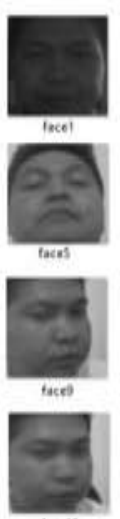

foeti
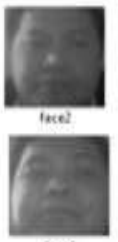

taseb
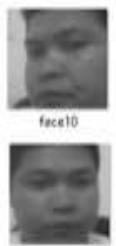

freit
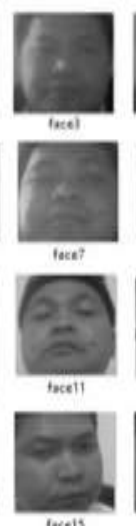

incels
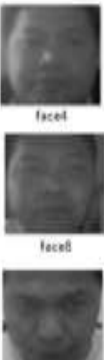

fack12

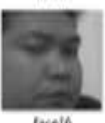

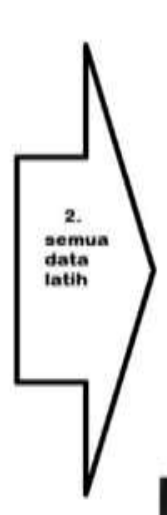

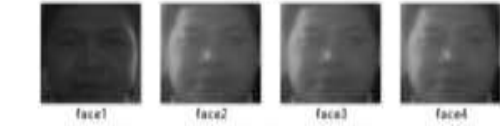

3. etra wajah deta latih yo attolak
1.

input eitra wajah
yg akan dikenali

Gambar 3.6 Klasifikasi pencocokan data wajah pada Machine Learning Adaboost

Pada tahap ini Machine Learning Adaboost mencocokan data input citra wajah dengan kumpulan data latih yang telah disimpan dalam galeri, secara berurutan setiap sample data latih dicocokan hingga akhirnya menemukan data wajah yang sesuai, data sample wajah yang tidak cocok langsung ditolak dan proses akan dilanjutkan pada data latih citra berikutnya. 


\section{Cascade Classifier}

Tahap selanjutnya yaitu cascade. Urutan filter pada cascade ditentukan oleh bobot yang diberikan AdaBoost. Filter dengan bobot paling besar diletakkan pada proses pertama kali, bertujuan untuk menghapus daerah gambar bukan wajah secepat mungkin.

Karakteristik dari algoritma Viola-Jones adalah adanya klasifikasi bertingkat. Klasifikasi pada algoritma ini terdiri dari tiga tingkatan dimana tiap tingkatan mengeluarkan subcitra yang diyakini bukan wajah. Hal ini dilakukan karena lebih mudah untuk menilai subcitra tersebut bukan wajah ketimbang menilai apakah subcitra tersebut berisi wajah. Gambar 3.7 menggambarkan bentuk alur kerja dari klasifikasi bertingkat.

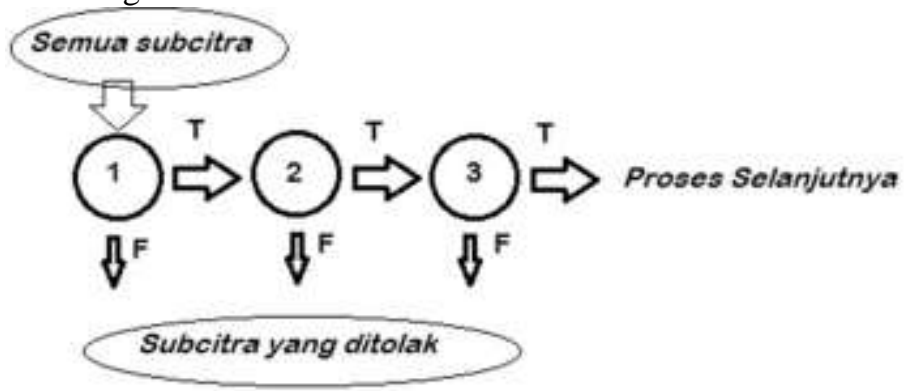

Gambar 3.7 Alur klasifikasi bertingkat (cascade)

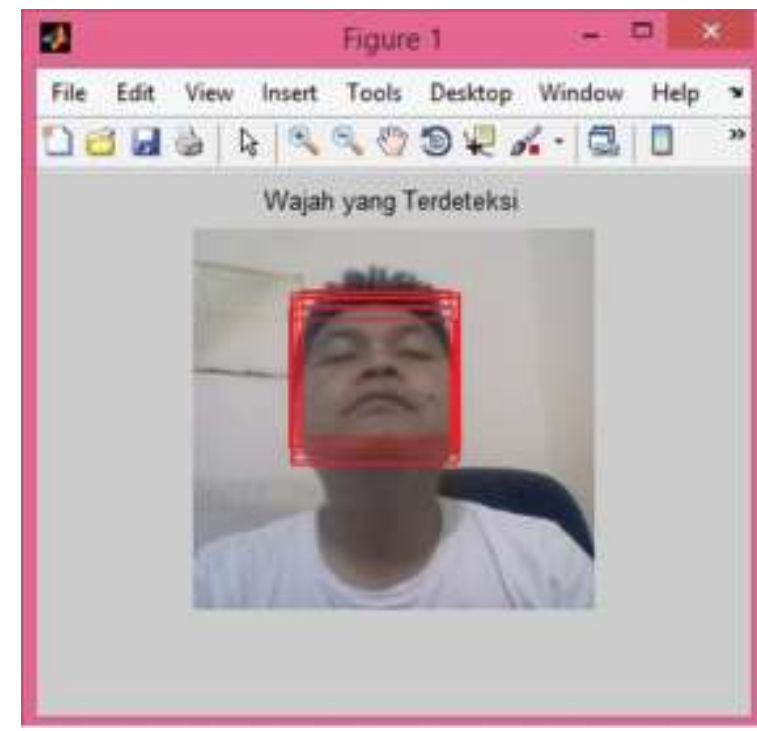

Gambar 3.8 Contoh Haar-Cascade klasifikasi

Pada klasifikasi tingkat pertama, tiap subcitra akan diklasifikasi menggunakan satu fitur. Hasil dari klasifikasi pertama ini berupa $\mathrm{T}$ (True) untuk gambar yang memenuhi fitur Haar tertentu dan F (False) bila tidak. Klasifikasi ini kira-kira akan menyisakan 50\% subcitra untuk diklasifikasi di tahap kedua. Hasil dari klasifikasi kedua berupa $\mathrm{T}$ (True) untuk gambar yang memenuhi proses integral image dan $\mathrm{F}$ (False) bila tidak. Seiring dengan bertambahnya tingkatan klasifikasi, maka diperlukan syarat yang lebih spesifik sehingga fitur yang digunakan menjadi lebih banyak. Jumlah subcitra yang lolos klasifikasi pun akan berkurang hingga mencapai jumlah sekitar 2\%. Hasil dari klasifikasi terakhir berupa T (True) untuk gambar yang memenuhi proses AdaBoost dan $\mathrm{F}$ (False) bila tidak.

Tahapan yang terakhir adalah menampilakan objek sampel gambar yang telah terdeteksi wajah ataupun bukan wajah, dengan memberi tanda bujur sangkar jika objek tersebut dianggap sebagai daerah (region) wajah manusia.

Sebuah perangkat deteksi wajah harus mampu memberi informasi apakah pada suatu gambar yang sembarang ukuran terdapat wajah manusia? Jika terdapat maka dimanakah letaknya? Salah satu kerangka kerja alami yang konsen pada bidang ini adalah klasifikasi biner, dengan konstruksi klasifikasi (classifier) mampu meminimalisasikan resiko kesalahan pendeteksian wajah. Dikarenakan tidak ada distribusi yang tepat untuk menggambarkan tingkat kemungkinan yang pasti yang menunjukkan bahwa terdapat wajah dalam sebuah gambar, maka dibutuhkan algoritma yang mampu 
meminimalis kedua tingkat kesalahan positif (false positive) dan tingkat kesalahan negatif (false negative) yang bertujuan untuk menampilkan hasil yang dapat diterima.

Tugas ini memerlukan sebuah perhitungan numerik yang akurat untuk mendeskripsikan dari kumpulan wajah yang manakah bagian wajah telah dipisahkan dari objek yang diberikan. Hal ini menunjukkan bahwa karakteristik yang dapat diekstrak melalui suatu ketentuan dalam algoritma latih yang disebut sebagai Adaboost, yang tergantung pada ketentuan klasifikasi lemah hingga kuat melalui suatu mekanisme voting. Sebuah klasifikasi yang lemah sejatinya tidak akan mampu menunjukkan deteksi yang baik.

Sebuah operasional algoritma juga harus mampu berkerja dengan perhitungan anggaran yang wajar. Teknik-teknik seperti integral image dan cascade menjadi perhatian pada algoritma viola-jones sungguh sangat efisien dengan menghasilkan realtime image yang berurutan dibangkitkan dari sebuah webcam standar, tampilannya cukup baik pada sebuah $P C$ standar.

\section{Desain Tampilan aplikasi deteksi dan pengenalan citra wajah :}

Pembuatan desain tampilan menggunakan perangakat GUI pada Matlab R2012a, untuk desain tampilan aplikas deteksi wajah terlihat pada gambar 4.10 dan gambar 4.11, sedangkan untuk desain tampilan aplikasi pengenalan wajah dapat ditunjukkan pada gambar 3.9 dan gambar 3.10.
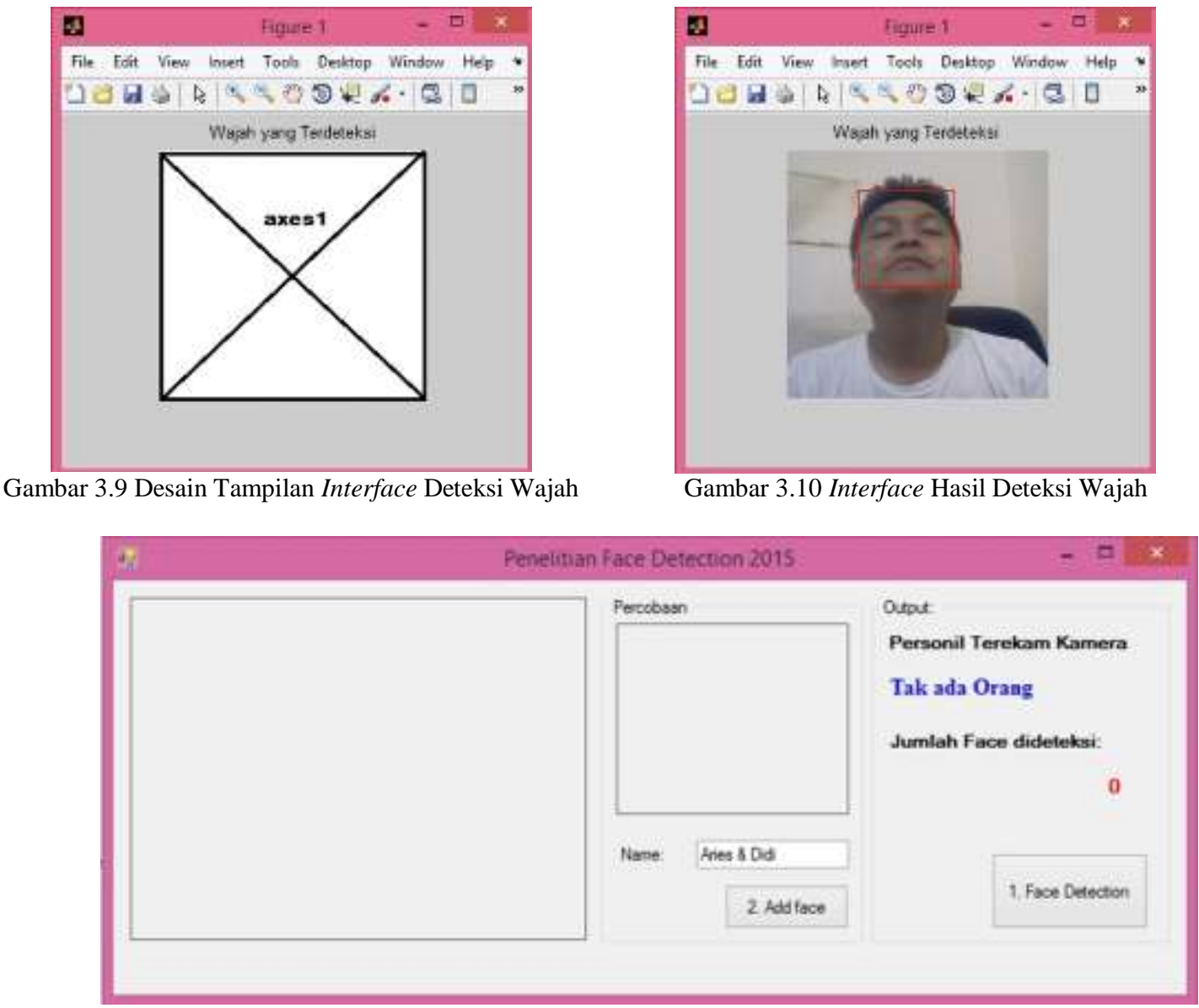

Gambar 3.11 Desain Interface Pengenalan Wajah 


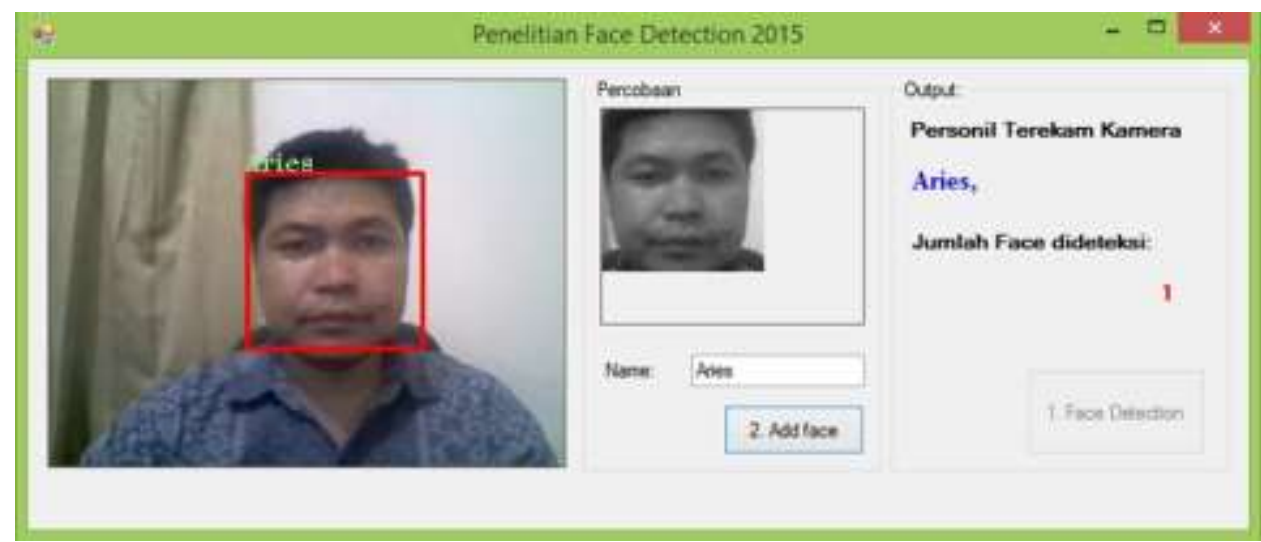

Gambar 3.12 Tampilan hasil Pengenalan Wajah

\section{Uji Aplikasi}

Pengujian aplikasi dilakukan melalui dua tahap, yaitu pertama pengujian aplikasi berdasarkan variasi sudut pengambilan citra wajah, kemudian yang kedua pengujian berdasarkan nilai threshold.

\section{Uji Aplikasi Berdasarkan Variasi Sudut Pengambilan Citra Wajah}

Dari hasil capture camera webcam dengan berbagai variasi sudut pengambilan citra wajah.

Tabel 3.1 Variasi sudut pengambilan citra wajah

\begin{tabular}{|c|c|c|c|}
\hline Variasi & Sisi Kiri & Sisi Depan & Sisi Kanan \\
\hline I & $30^{0}$ & $-15^{0}$ & $30^{0}$ \\
\hline II & $45^{0}$ & $0^{0}$ & $45^{0}$ \\
\hline III & $60^{0}$ & $15^{0}$ & $60^{0}$ \\
\hline IV & $75^{0}$ & $30^{0}$ & $75^{0}$ \\
\hline
\end{tabular}

Beberapa contoh sample 30 buah data latih yang diperoleh dari hasil capture camera webcam dapat ditunjukkan pada gambar 3.13 berikut ini.

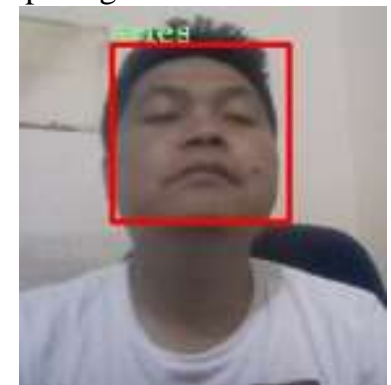

Sisi Depan 300

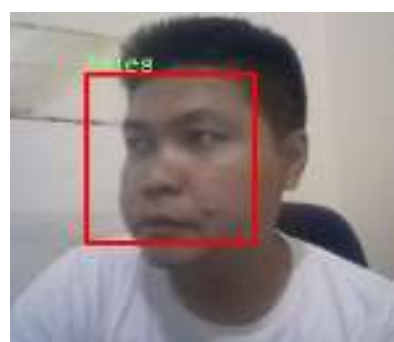

Sisi Kiri 600

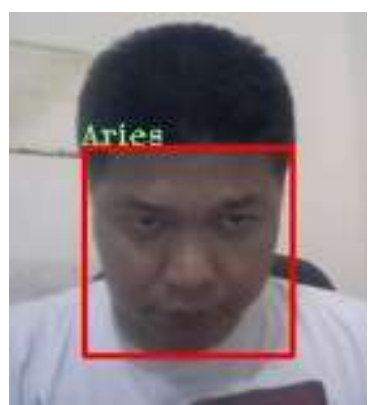

Sisi Depan -15

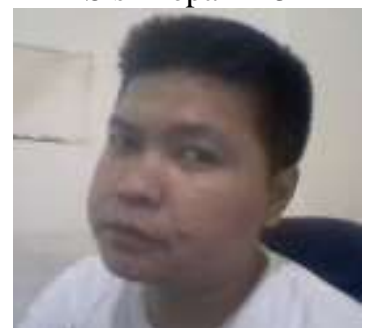

Sisi Kiri 750

Gambar 3.13 Beberapa sample citra wajah hasil capture camera webcam

Maka diperoleh nilai Akurasi seperti yang ditunjukkan pada Tabel 3.2 Hasil Uji Variasi Sudut Pengambilan Citra Wajah. 
Tabel 3.2 Hasil Uji Variasi Sudut Pengambilan Citra Wajah

\begin{tabular}{|c|c|c|c|}
\hline Variasi & Jumlah Terdeteksi & Jumlah Dikenali & $\begin{array}{c}\text { \% } \\
\text { Akurasi }\end{array}$ \\
\hline I & 27 & 24 & $88.89 \%$ \\
\hline II & 25 & 21 & $84.00 \%$ \\
\hline III & 23 & 18 & $78.26 \%$ \\
\hline IV & 21 & 14 & $66.67 \%$ \\
\hline
\end{tabular}

Dengan Tingkat akurasi dihitung melalui rumus :

$$
\% \text { akurasi }=\frac{\sum \text { dikenali }}{\sum \text { terdeteksi }} x 100 \%
$$

Sumber : Mahendra Lubis A, Joson J \& Zullidar M [13]

$$
\begin{aligned}
\% \text { Akurasi variasi I }=\frac{24}{27} \times 100 \%=88.89 \% \\
\% \text { Akurasi variasi } I I=\frac{21}{25} \times 100 \%=84.00 \% \\
\% \text { Akurasi variasi III }=\frac{18}{23} \times 100 \%=78.26 \% \\
\% \text { Akurasi variasi } I V=\frac{14}{21} \times 100 \%=66.67 \%
\end{aligned}
$$

Dari tabel 3.2 Hasil Uji Variasi Sudut Pengambilan Citra Wajah menunjukkan bahwa tingkat Akurasi Tertinggi dicapai pada saat variasi I dimana sudut pengambilan citra wajah sisi kiri $30^{\circ}$, sisi depan $-15^{\circ}$ dan sisi kanan $30^{\circ}$. Hal ini berarti aplikasi berfungsi memdeteksi wajah dengan sangat baik pada posisi wajah yang relatif bersudut rendah terhadap posisi frontal (wajah menghadap lurus ke depan).

\section{Uji Aplikasi Berdasarkan Threshold}

Uji Aplikasi Berdasarkan batas Threshold yang masih dapat terdeteksi baik oleh mata normal maupun oleh aplikasi. Adapun simulasi uji threshold dilakukan mengunakan Matlab R2012a dieroleh tampilan sebagai berikut.

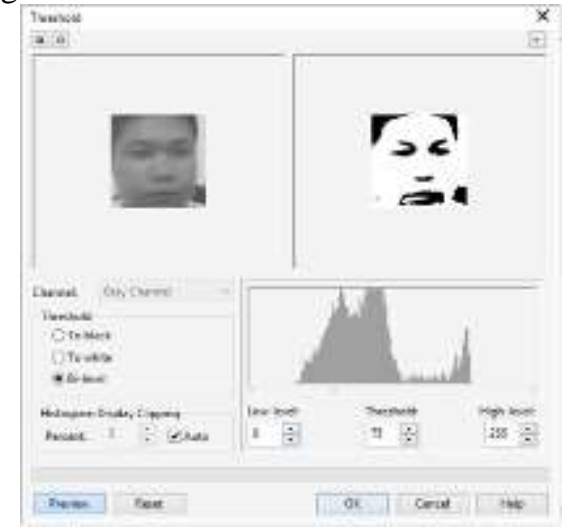

Uji Threshold 75

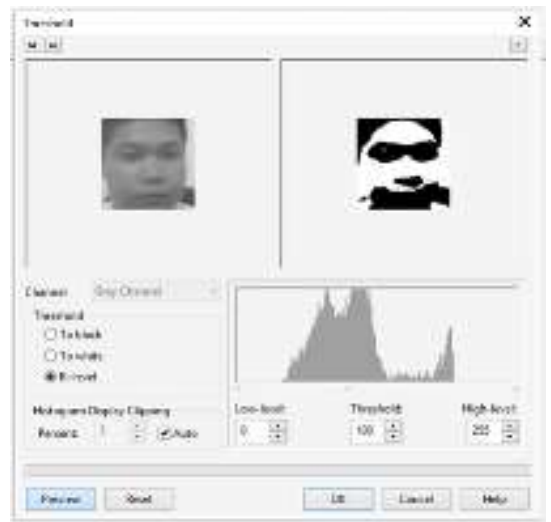

Uji Threshold 100 


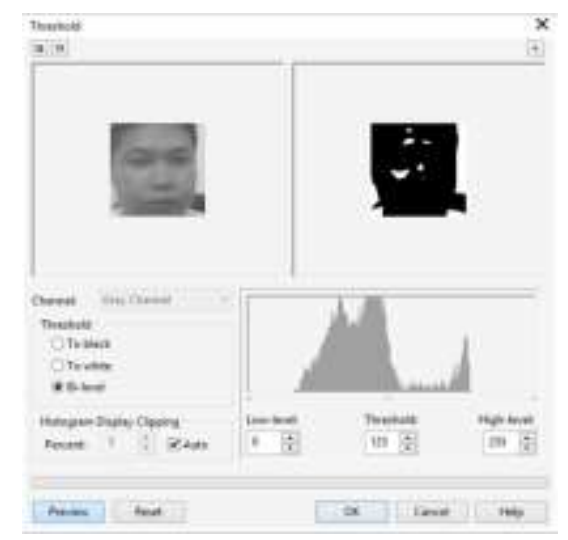

Uji Threshold 125

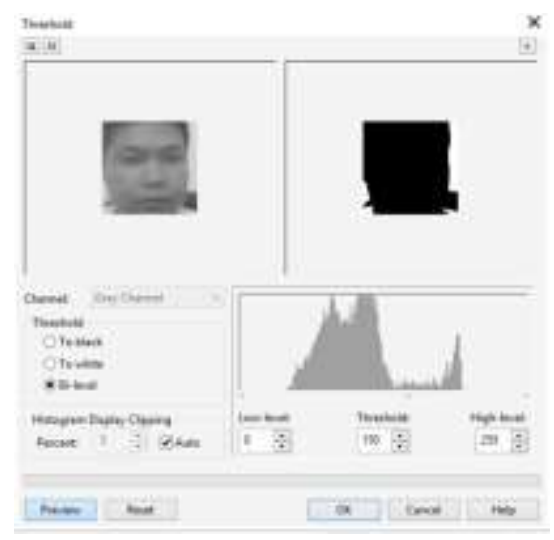

Uji Threshold 150

Gambar 3.14 Hasil Uji Threshold menggunakan Matlab R21012a

Hasil simulasi threshold pada variasi citra wajah ditunjukkan pada Tabel 3.3

Tabel 3.3 Hasil Uji Threshold pada Citra Wajah yang Dikenali

\begin{tabular}{|c|c|c|c|}
\hline $\begin{array}{c}\text { Nilai } \\
\text { Threshold }\end{array}$ & Jumlah Terdeteksi & Jumlah Dikenali & $\begin{array}{c}\text { \% } \\
\text { Akurasi }\end{array}$ \\
\hline 75 & 11 & 10 & $90.90 \%$ \\
\hline 100 & 12 & 9 & $75.00 \%$ \\
\hline 125 & 14 & 8 & $57.15 \%$ \\
\hline 150 & 15 & 7 & $46.67 \%$ \\
\hline
\end{tabular}

$\%$ Akurasi Threshold $75=\frac{10}{11} \times 100 \%=90.90 \%$

$\%$ Akurasi Threshold $100=\frac{9}{12} \times 100 \%=75.00 \%$

$\%$ Akurasi Threshold $125=\frac{8}{14} \times 100 \%=57.15 \%$

$\%$ Akurasi Threshold $150=\frac{7}{15} \times 100 \%=46.67 \%$

Pada Tabel 3.3 di atas dapat dilihat bahwa simulasi nilai threshold 75 memiliki akurasi tertinggi dan jumlah dikenali tertinggi yaitu $90.90 \%$ pada aplikasi pendeteksian dan pengenalan citra wajah dengan sample 30 citra wajah sebagai data latih.

\section{PENUTUP}

Kesimpulan

Berdasarkan pembahasan pada bab sebelumnya dalam penelitian ini maka dapat ditarik kesimpulan bahwa :

1. Implentasikan metode Viola - Jones untuk mendeteksi citra wajah manusia dengan berbagai posisi citra wajah dapat dilakukan dengan bantuan perangkat Matlab R2012a.

2. Tingkat akurasi hasil citra wajah manusia yang terdeteksi oleh metode Viola - Jones ditunjukkan dari hasil uji simulasi terhadap sejumlah data latih sebagai berikut :

a. Tingkat akurasi untuk deteksi dan pengenalan wajah akan semakin baik pada saat posisi wajah variasi I yang relatif bersudut rendah terhadap posisi frontal (wajah menghadap lurus ke depan) sisi kiri $30^{\circ}$, sisi depan $-15^{0}$ dan sisi kanan $30^{\circ}$ yaitu sebesar $88.89 \%$

b. Semakin rendah nilai threshold, maka tingkat akurasi kemiripan citra wajah input dengan citra wajah dalam data training, terbukti pada nilai threshold 75 memiliki akurasi tertinggi dan jumlah dikenali tertinggi yaitu $90.90 \%$. 


\section{Saran}

Berikut beberapa saran yang diajukan untuk pengembangan aplikasi ini lebih lanjut :

- Pengambilan citra wajah masih bersifat subjektif, perlu dilakukan standarisasi pengukur sudut wajah untuk menghasilkan presisi sudut wajah dengan aligment yang lebih baik lagi.

- Pada penelitian ini sampel data latih citra wajah yang digunakan masih sedikit dan bersifat subjektif, oleh karena itu perlu dikaji lagi apabila aplikasi ini digunakan pada data latih citra wajah dalam skala besar dan banyak.

\section{DAFTAR PUSTAKA}

Aditya Wisnu W I, Anthony F \& Andrian S (2009). Analisis dan Perancangan Sistem Identifikasi Berbasis Wajah dengan Menggunakan Pustaka Open CV. Jurusan Teknik Informatika Universitas Binus.

Cho Junguk, Mirzaei Shahnam, Oberg Jason, \& Kastner Ryan (2009). FPGA-Based Face Deyection System Using Haar Classifiers. Department of Computer Science and Engineering University of California, San Diego United States, \& Department of Electrical and Computer Engineering University of California, Santa Barbara, United states.

Dwisnanto Putro M, Bharata Adji T, \& Winduratna B (2012). Deteksi Wajah dengan Menggunakan Metode Viola-Jones. Magister Instrumentasi Elektro FT UGM. Seminar Nasional "Science, Engineering and Technology (SCiETec).

Eka Puspitasari D, Hidayatno A, \& Ajulian Zahra A. Pengenalan Wajah Menggunakan Metode PCA untuk Aplikasi Sistem Keamanan Rumah. Jurusan Teknik Elektro Fakultas Teknik Universitas Diponegoro, Semarang.

Gunadi K \& Pongsitanan Reinard S. Pembuatan Perangkat Lunak Pengenalan Wajah Menggunakan PCA. Fakultas Teknologi Industri, Jurusan Teknik Informatika - Universitas Kristen Petra. Jurnal Informatika Vol. 2, No. 2, Nov 2001:67-81.

Halimah \& Matulatan T. Pengenalan Wajah dengan Menggunakan Metode PCA. Jurusan Informatika, Fakultas Teknik, Universitas Maritim Raja Ali Haji, Senggarang Tanjungpinang.

Heisele B, Poggio T \& Pontil M (2000). Face Detection in Still Gray Image. Massachusetts Institute of Technology Artificial Intelligen Laboratory and Center for Bioligical and Computational Learning Department of Brain and Cognitive Sciences. Publication AIM-1687.ps.Z

Hjelmas E, \& Kee Loe B (2001). Face Detection : A Survey. Department of Informatics, University of Oslo \& Department of Meteorology, University of Edinburgh, Scotland, United Kingdom. Computer Vision and Image Understanding 83, 236-274 (2001).

Indra (2012). Sistem Pengenalan Wajah dengan Metode Eigenface untuk Absensi pada PT. Florindo Lestari. Fakultas Teknologi Informasi Universitas Budi Luhur, Jakarta. Seminar Nasional Teknologi Informasi \& Komunikasi Terapan (Semantik) 2012, ISBN 979-26-0255.

Indrawan, P (2012). Implementasi Sistem Pengenalan Wajah sebagai Penghubung Jejaring Sosial. Fakultas Teknik Program Studi Teknik Komputer, Depok : Universitas Indonesia.

Lin Hwe-Jen, Wang Shu-Yi, Yen Shwu-Huey, \& Kao Yang-Ta (2005). Face Detection Based on Skin Color Segmentation and Neural Network. Department of Computer Science and Information Engineering, Tamkang University, Taipe, Taiwan, China. 0-7803-942294/05/\$20.00@2005 IEEE.

Luthfie Nur S. Implementasi Jaringan Saraf Tiruan Backpropagation pada Aplikasi Pengenalan Wajah dengan Jarak yang Berbeda Menggunakan MATLAB 7.0. Jurusan Teknik Informatika, Universitas Gunadarma.

Mahendra Lubis A, Joson J \& Zullidar M. Pengembangan Aplikasi Sistem Pengenalan Wajah Menggunakan Local Binary Pattern dengan Variasi Posisi Wajah. Jurusan Teknik Informatika, Fakultas Ilmu Komputer, Universitas Bina Nusantara, Jakarta.

Prasetyo E, \& Rahmatun I. Desain Sistem Pengenalan Wajah dengan Variasi Ekspresi dan Posisi Menggunakan Metode Eigenface. Depok: Universitas Gunadarma.

Pratikno H. Sistem Absensi Berbasiskan Pengenalan Wajah Secara Realtime Menggunakan Webcam dengan Metode PCA. Program Studi Sistem Informasi, STIKOM Surabaya.

Purwanto E J. Pengenalan Wajah Melalui Webcam dengan Menggunakan Algoritma PCA dan LDA. Fakultas Teknik dan Ilmu Komputer, Jurusan Informatika, Universitas Komputer Indonesia. 
Sepritahara (2012). Sistem Pengenalan Wajah (Face Recognition) Menggunakan Metode Hidden Markov Model (HMM). Fakultas Teknik Universitas Indonesia Program Studi Teknik Elektro Depok. Januari 2012.

Singh Sanjay Kr, Chauhan D.S, Vatsa Mayank, \& Singh Richa (2003). A Robust Skin Color Based Face Detection Algorithm. Department of Computer Science and Engineering-Institute of Engineering and Technology Jaupur-222002, Uttar Pradesh Toratoryechnical University Lucknow-226021, Indian Institute of Technology Kanpur-208016 India. Tamkang Journal of Science and Engineering, Vol. 6, No. 4, pp.. 227-234 (2003).

Syah Putra, R (2013). Perancangan Aplikasi Absensi dengan Deteksi Wajah Menggunakan Eigenface. Program Studi Teknik Informatika, STMIK Budi Darma Medan. Pelita Informatika Budi Darma, Vol: IV, Nomor:2, ISSN : 2301-9425.

Viola P \& Jones Michael J (2004). Robust Real-Time Face Detection. Microsoft Research, One Microsoft Way, Redmond, WA 98052, USA. Mitshubishi Electric Research Laboratory, 201 Broadway, Cambridge, MA 02139, USA. International Journal of Computer Vision 57(2), 137154, 2004. Kluwer Academic Publisher. Manufactured in The Netherland.

Wahyudi E, Kusuma H, \& Wirawan (2011). Perbandingan Unjuk Kerja Pengenalan Wajah Berbasis Fitur local Binary Pattern dengan Algoritma PCA dan Chi Square. Surabaya : Jurusan Teknik Elektro ITS. Seminar on Inteligent and It's Applications, ISSN 2088-4796.

Wirawan Margono A, Lim R, \& Gunawan I (2004). Pengenalan Wajah Menggunakan Embedded Hidden Markov Models. Fakultas Teknologi Industri, Jurusan Teknik Informatika, Universitas Kristen Petra. IES 2004-Politeknik Elektronika Negeri Surabaya-ITS.

Wu-Chi Hu, Ching-Yu Yang, Deng-Yuan \& Chung-Hsiang Huang (2010). Feature-based Face Detection Against Skin-color Like Background with Varying Illumination. Department of Computer Science and Information Engineering, National Penghu University of Science and Technology, Taiwan. Journal of Information Hiding and Multimedia Signal Processing, Ubiquitous International, ISSN 2073-4212, Vol:2 Number 2, April 2011.

Yi-Qing Wang (2014). An Analysis of the Viola-Jones Face Detection Algorithm. Published in Image Processing On Line on 2014-06-26, Submitted on 2013-08-31, accepted on 2014-05-09. ISSN 2015-1232. CMLA, ENS Cachan, France (yiqing.wang@cmla.ens-cachan.fr). 